\title{
ANALISIS PENGARUH STOCK SPLIT TERHADAP VOLUME PERDAGANGAN, HARGA SAHAM, DAN ABNORMAL RETURN PADA PERUSAHAAN YANG TERDAFTAR DI BEI PERIODE 2017 - 2018
}

\author{
Agus Amanda Tanoyo \\ Program Studi Magister Manajemen Universitas Tarumanagara \\ agus.117172051@stu.untar.ac.id
}

\begin{abstract}
This study aims to determine the difference in the trading volume activity, stock prices and abnormal returns before and after the announcement of a stock split. The population of this study are all companies listed in Indonesia Stock Exchange that take corporate action in the form of stock split at period 2017-2018. Sampling using purposive sampling. Based on the sampling criteria predetermined number of samples acquired 24 stocks. The analytical method used is the analysis Wilcoxon Signed Rank Test with the observation period (event window) is 14 days. The results showed that there were differences in the trading volume activity and stock prices before and after the announcement of stock split, while the last hypothesis showed that there were no differences in abnormal returns before and after the announcement of stock split.
\end{abstract}

\begin{abstract}
Abstrak : Penelitian ini bertujuan untuk mengetahui adanya perbedaan yang signifikan antara volume perdagangan saham, harga saham, dan abnormal return sebelum dan sesudah pengumuman stock split. Populasi penelitian ini adalah seluruh perusahaan yang terdaftar di Bursa Efek Indonesia yang melakukan stock split periode 2017-2018. Pengambilan sampel menggunakan teknik purposive sampling. Berdasarkan kriteria pengambilan sampel yang telah ditetapkan diperoleh jumlah sampel 24 perusahaan. Metode analisis yang digunakan adalah analisis uji Wilcoxon Signed Rank Test dengan periode pengamatan (event window) adalah 14 hari. Hasil penelitian ini menunjukkan bahwa terdapat perbedaan volume perdagangan saham dan harga saham sebelum dan sesudah pengumuman stock split. Sedangkan untuk variabel abnormal return, tidak ada perubahan signifikan sebelum dan sesudah pengumuman stock split.
\end{abstract}

Keywords : stock split, trading volume activity, stock prices, abnormal return.

\section{PENDAHULUAN}

Likuiditas suatu perusahaan berhubungan erat dengan masalah kemampuan suatu perusahaan untuk memenuhi kewajiban finansialnya yang harus segera dipenuhi, sedangkan likuiditas saham merupakan tingkat kemudahan untuk menjual atau membeli saham pada harga yang wajar. Menurut Koetin (2000), likuiditas saham merupakan mudahnya suatu saham yang dimiliki seseorang untuk dapat diubah menjadi uang tunai melalui mekanisme pasar modal. Perusahaan yang tingkat likuiditasnya baik akan memperdagangkan sahamnya dalam pasar modal, dimana pasar modal merupakan tempat perusahaan untuk menghimpun dana yang berfungsi untuk membiayai seluruh kegiatan perusahaan, dimana masyarakat diikutsertakan langsung didalamnya. Dalam hal ini masyarakat yang diikutsertakan adalah masyarakat yang menanamkan dananya ke dalam suatu perusahaan atau yang kita kenal dengan istilah berinvestasi, dengan cara membeli saham dari perusahaan yang terdaftar di BEI (Bursa Efek Indonesia).

Informasi yang dipublikasikan di pasar modal diantaranya adalah pemecahan saham (stock split). Stock split merupakan bentuk dari corporate action dalam pasar modal, yang akan menjadi pertimbangan para investor untuk menentukan keputusannya. Informasi ini dapat memiliki nilai jika keberadaan informasi tersebut menyebabkan investor melakukan 
transaksi di pasar modal. Selain itu, informasi yang beredar di bursa efek atau pasar modal, seperti kondisi keuangan atau kinerja suatu perusahaan akan mempengaruhi harga saham yang ditawarkan pada publik dan juga berbagai isu lainnya yang secara langsung dapat mempengaruhi profitabilitas perusahaan di masa depan.

Cara yang dapat ditempuh oleh perusahaan untuk mengatasi masalah tingginya harga pasar saham tersebut adalah dengan melakukan corporate action berupa pemecahan saham atau yang seringkali disebut stock split. Stock split pada umumnya dilakukan pada saat harga saham dinilai terlalu tinggi sehingga akan mengurangi kemampuan investor untuk membelinya. Dengan dilakukannya stock splitmaka harga saham turun dan diharapkan akan menarik investor-investor kecil untuk membeli saham-saham tersebut.

Berdasarkan hal tersebut maka dapat ditarik suatu kesimpulan sementara bahwa peristiwa stock split mengandung suatu informasi sehingga pasar modal bereaksi yang ditunjukkan dengan adanya perubahan volume perdagangan saham, harga saham dan abnormal return saham setelah stock split. Kenaikan aktivitas perdagangan suatu saham otomatis akan berakibat terhadap kenaikan harga saham perusahaan tersebut, yang selanjutnya berpengaruh pada return pemegang saham dan akhirnya tujuan perusahaan untuk mencapai seluas-luasnya kesejahteran para pemegang saham tercapai.

\section{TELAAH KEPUSTAKAAN}

\section{Pasar Modal}

Pasar modal (capital market) merupakan pasar untuk berbagai instrumen keuangan jangka panjang yang bisa diperjualbelikan, baik surat utang (obligasi), ekuiti (saham), reksadana, instrumen derivatif maupun instrumen lainnya.

\section{Efficient Market Theory}

Konsep efisiensi pasar menyatakan bahwa pemodal selalu menyertakan faktor informasi yang tersedia kedalam keputusan mereka sehingga terefleksi pada harga yang mereka transaksikan, sehingga dapat disimpulkan bahwa harga yang berlaku di pasar telah mengandung informasi tersebut (Ang, 2012).

\section{Signalling Theory}

Signal adalah suatu tindakan yang diambil perusahaan untuk memberi petunjuk bagi investor tentang bagaimana manajemen memandang prospek perusahaan (Brigham dan Houston, 2001:36). Informasi yang dipublikasikan sebagai suatu pengumuman akan memberikan sinyal bagi investor dalam pengambilan keputusan investasi.

\section{Stock Split}

Pemecahan saham (stock split) adalah memecah lembar saham menjadi $\mathrm{n}$ lembar saham, dimana harga per lembar saham setelah stock split adalah sebesar $1 / \mathrm{n}$ dari harga sebelumnya.

\section{Volume Perdagangan Saham}

Salah satu cara untuk mengukur tingkat likuiditas saham adalah dengan mengguanakan Trading Volume Activity (TVA). Perkembangan volume perdagangan saham mencerminkan kekuatan antara permintaan dan penawaran yang merupakan interpretasi dari tingkah laku investor (Ang, 2012).

\section{Abnormal Return Saham}

Abnormal return merupakan kelebihan dari imbal hasil yang sesungguhnya terjadi (actual return) terhadap imbal hasil normal. Imbal hasil normal merupakan imbalhasil ekspektasi (expected return) atau imbal hasil yang diharapkan oleh investor (Jogiyanto, 2008)

\section{Kaitan antar Variabel}

\section{Pengaruh stock split terhadap volume perdagangan saham}

Ikenberry dkk (2006) dalam penelitiannya berpendapat bahwa "stock split 
mengakibatkan terjadinya penataan kembali harga saham pada rentang yang lebih rendah", dengan mengarahkan harga saham pada rentang tertentu diharapkan semakin banyak pelaku dalam pasar yang akan terlibat dalam perdagangan, dan akan meningkatkan likuiditas saham di bursa. Besar kecilnya perubahan rata-rata trading volume activity sebelum dan sesudah pemecahan merupakan ukuran besar kecilnya akibat yang ditimbulkan dari informasi pemecahan saham. Apabila volume saham yang diperdagangkan (trading) lebih besar daripada volume saham yang diterbitkan (listing) maka semakin likuid saham tersebut (Damayanti, 2014). Apabila jumlah lembar saham yang diperjualbelikan di pasar lebih banyak jumlahnya/volume saham yang diperdagangkan meningkat, akan menarik lebih banyak investor untuk bertransaksi dan saham akan semakin aktif diperdagangkan, sehingga akan meningkatkan likuiditas saham tersebut.

Berdasarkan uraian tersebut, hipotesis penelitian (H1) adalah:

$\mathrm{H}_{1}$ : Terdapat perbedaan volume perdagangan saham yang signifikan pada periode sebelum dan sesudah stock split pada perusahaan yang terdaftar di Bursa Efek Indonesia periode 2017-2018.

\section{Pengaruh stock split terhadap harga saham}

Menurut trading range theory bahwa keputusan stock split dilatarbelakangi adanya tingkat harga saham yang tinggi serta memiliki tujuan untuk membuat saham lebih aktif diperdagangkan/likuiditas meningkat. Harga saham yang terlalu tinggi (overpriced) menyebabkan kurang aktifnya saham tersebut diperdagangkan. Hal ini menyebabkan investor kecil yang hanya memiliki modal yang terbatas tidak memiliki kesempatan untuk membeli saham yang harganya terlalu tinggi. Adanya aktivitas stock split, harga saham menjadi tidak terlalu tinggi sehingga makin banyak investor bertransaksi (Marwata, 2001).

Berdasarkan uraian tersebut, hipotesis penelitian (H2) adalah:

$\mathrm{H}_{2}$ : Terdapat perbedaan harga saham yang signifikan pada periode sebelum dan sesudah stock split pada perusahaan yang terdaftar di Bursa Efek Indonesia periode 2017-2018.

\section{Pengaruh stock split terhadap abnormal return saham}

Pasar akan bereaksi pada saat pengumuman informasi itu diterima oleh pasar atau investor. Reaksi tersebut ditunjukkan dengan adanya perubahan harga dari sekuritas yang bersangkutan dengan menggunakan pengukuran abnormal return, sehingga dapat dikatakan bahwa pengumuman yang memiliki kandungan informasi akan memberikan abnormal return kepada pasar dan sebaliknya. Beberapa pengertian di atas dapat memberikan kesimpulan bahwa studi peristiwa dikembangkan untuk menganalisis reaksi pasar terhadap suatu peristiwa yang informasinya dipublikasikan. Peristiwa tersebut meliputi peristiwa ekonomi maupun non-ekonomi untuk mengetahui ada tidaknya abnormal return yang diperoleh pemegang saham.

Berdasarkan uraian tersebut, hipotesis penelitian (H3) adalah:

$\mathrm{H}_{3}$ : Terdapat perbedaan abnormal return saham yang signifikan pada periode sebelum dan sesudah stock split pada perusahaan yang terdaftar di Bursa Efek Indonesia periode 2017-2018.

\section{METODOLOGI PENELITIAN}

Jangka waktu yang digunakan dalam penelitian ini adalah 14 hari, yaitu tujuh hari sebelum peristiwa stock split $(\mathrm{t}-7)$ dan tujuh hari setelah stock split $(\mathrm{t}+7)$. Penentuan event window tersebut diharapkan pasar telah bereaksi penuh dan dapat dilihat kecepatan reaksinya. Selain itu, untuk menghindari pengaruh dari informasi lain yang dapat mempengaruhi perubahan harga saham dan volume perdagangan saham pada perusahaan (emiten) yang bersangkutan. Jika periode peristiwa diambil terlalu lama, dikhawatirkan adanya peristiwa lain yang cukup signifikan mempengaruhi hasilnya. 
Populasi dalam penelitian ini adalah perusahaan yang melakukan pengumuman pemecahan saham di Bursa Efek Indonesia (BEI) periode 2017-2018. Teknik sampel yang digunakan yaitu purposive sampling, dimana merupakan cara penarikan sampel yang dilakukan dengam memilih subyek berdasarkan kriteria spesifik yang diterapkan peneliti. Untuk sampel bersyarat ditentukan dengan kriteria tertentu atau judgement sampling. Adapun sampel yang dipilih dalam penelitian ini adalah perusahaan yang melakukan stock split tahun 2017-2018. Variabel dependen dalam penelitian ini adalah volume perdagangan saham (trading volume activity), harga saham, dan abnormal return saham.

Data yang terkumpul akan dianalisis secara bertahap dengan dilakukan analisis statistik deskriptif terlebih dahulu, selanjutnya dilakukan pengujian statistik dengan uji distribusi normal dengan menggunakan uji Kolmogorov-Smirnov Test. Tahap selanjutnya dilakukan pengujian hipotesis parsial untuk masing-masing variabel penelitian dengan menggunakan uji analisis Paired Sample T-Test apabila data berdistribusi normal dan model uji analisis Wilcoxon Signed Rank apabila data berdistribusi tidak normal. Untuk tingkat signifikansi atau nilai alfa $(\alpha)$, menurut Ghozali (2009) nilai alfa yang umum dipakai adalah 0,05 , kemudian pada penelitian ini ditetapkan tingkat signifikansi atau probabilitas kesalahan untuk menolak $\mathrm{H}_{0}$ untuk seluruh pengujian adalah sebesar 0,05 atau $5 \%$.

\section{HASIL PENELITIAN DAN PEMBAHASAN}

Selama periode pengamatan penelitian, yaitu antara tahun 2017-2018, jumlah perusahaan yang dijadikan sampel yang akan diteliti adalah sebanyak 24 perusahaan. Analisis statistik deskriptif dapat dilihat pada Tabel 1, yang memberikan gambaran tentang karakteristik sampel dari variabel - variabel yang diteliti, berupa nilai minimum, nilai maksimum, nilai rata-rata (mean) dan standar deviasi dari rata-rata sampel penelitian.

Hasil pengujian normalitas dengan menggunakan uji Shapiro-Wilk dapat dilihat pada Tabel 2. Karena jumlah saham yang dianalisa sebanyak 24 saham perusahaan ( $<50$ sampel $)$, maka peneliti menggunakan signifikansi pada bagian Shapiro-Wilk. Sedangkan jika jumlah data lebih besar daripada 50, maka peneliti menggunakan signifikansi pada bagian Kolmogrov-Smirnov. Berdasarkan hasil uji normalitas pada Tabel 2 dapat dilihat bahwa volume, harga saham dan abnormal return pada saat sebelum dan sesudah peristiwa stock split memiliki nilai sigifikansi kurang dari 0,05. Berdasarkan hal tersebut data dapat disimpulkan bahwa data volume perdagangan, harga saham, dan abnormal return tidak berdistribusi normal. Selanjutnya dapat dilakukan analisis data mrnggunakan metode statistik non parametrik yaitu uji Wilcoxon Signed Rank Test.

Tabel 1. Hasil Analisis Deskriptif Sebelum dan Sesudah Pengumuman Stock Split

\begin{tabular}{|l|r|r|r|r|r|r|}
\hline & $\begin{array}{r}\text { Volume } \\
\text { Sebelum }\end{array}$ & $\begin{array}{c}\text { Volume } \\
\text { Sesudah }\end{array}$ & $\begin{array}{c}\text { Harga } \\
\text { Sebelum }\end{array}$ & $\begin{array}{c}\text { Harga } \\
\text { Sesudah }\end{array}$ & $\begin{array}{c}\text { Return } \\
\text { Sebelum }\end{array}$ & $\begin{array}{c}\text { Return } \\
\text { Sesudah }\end{array}$ \\
\hline $\mathrm{n}$ & 24 & 24 & 24 & 24 & 24 & 24 \\
Mean & .001105 & .001377 & 1113.75 & 1137.08 & .001377 & .0022610 \\
Std. Deviation & .001684 & .001909 & 1703.97 & 1698.384 & .008421 & .021105 \\
Variance & .000 & .000 & 2903533 & 2884508 & .000 & .000 \\
Skewness & 2.128 & 1.850 & 2.495 & 2.464 & 1.670 & 2.578 \\
Std. Error of & .472 & .472 & .472 & .472 & .472 & .472 \\
Skewness & 3.663 & 2.691 & 5.609 & 5.472 & 3.672 & 9.666 \\
Kurtosis & .918 & .918 & .918 & .918 & .918 & .918 \\
Std. Error of Kurtosis & .000013 & .000030 & 136.00 & 133.00 & -.012035 & -.024886 \\
Minimum & .006113 & .006754 & 6555.00 & 6575.00 & .026715 & .083984 \\
Maximum & & & & & & \\
\hline
\end{tabular}


Tabel 2. Hasil Uji Normalitas Kolmogrov-Smirnov dan Shapiro-Wilk

\begin{tabular}{|l|r|r|r|r|r|r|}
\hline & \multicolumn{3}{|c|}{ Kolmogorov-Smirnov $^{\mathrm{a}}$} & \multicolumn{3}{c|}{ Shapiro-Wilk } \\
\cline { 2 - 7 } & Statistic & \multicolumn{1}{c|}{ df } & \multicolumn{1}{c|}{ Sig. } & Statistic & \multicolumn{1}{c|}{ df } & \multicolumn{1}{c|}{ Sig. } \\
\hline Volume_Sebelum & .258 & 24 & .000 & .649 & 24 & .000 \\
Volume_Sesudah & .244 & 24 & .001 & .717 & 24 & .000 \\
Harga_Sebelum & .353 & 24 & .000 & .586 & 24 & .000 \\
Harga_Sesudah & .343 & 24 & .000 & .593 & 24 & .000 \\
Return_Sebelum & .206 & 24 & .010 & .843 & 24 & .002 \\
Return_Sesudah & .209 & 24 & .008 & .759 & 24 & .000 \\
\hline
\end{tabular}

\section{Pengujian Hipotesis}

Pengujian hipotesis dilakukan menggunakan uji Wilcoxon Signed Ranked Test dengan tingkat signifikansi 0,05 . Pada Tabel 3, hasil pengujian variabel volume perdagangan saham menunjukan nilai signifikasi $<0.05$ yaitu sebesar 0.018 . Oleh sebab itu maka $\mathrm{H}_{0}$ ditolak dan dapat disimpulkan bahwa terdapat perbedaan yang signifikan pada volume perdagangan saham sebelum dan sesudah stock split.

Tabel 3. Hasil Uji untuk variabel Volume Perdagangan Saham

\begin{tabular}{|l|r|}
\hline & \multicolumn{2}{|c|}{$\begin{array}{l}\text { Volume Sesudah - } \\
\text { Volume Sebelum }\end{array}$} \\
\hline $\mathrm{Z}$ & $-2.371^{\mathrm{b}}$ \\
$\begin{array}{l}\text { Asymp. Sig. (2- } \\
\text { tailed) }\end{array}$ & .018 \\
\hline
\end{tabular}

Pada Tabel 4, hasil pengujian variabel volume perdagangan saham menunjukan nilai signifikasi $<0.05$ yaitu sebesar 0.022 . Oleh sebab itu maka $\mathrm{H}_{0}$ ditolak dan dapat disimpulkan bahwa terdapat perbedaan yang signifikan pada harga saham sebelum dan sesudah stock split.

Tabel 4. Hasil Uji untuk variabel Volume Perdagangan Saham

\begin{tabular}{|l|r|}
\hline & \multicolumn{2}{|c|}{$\begin{array}{c}\text { Harga Sesudah }- \\
\text { Harga Sebelum }\end{array}$} \\
\hline$Z$ & $-2.286^{\mathrm{b}}$ \\
$\begin{array}{l}\text { Asymp. Sig. (2- } \\
\text { tailed) }\end{array}$ & .022 \\
\hline
\end{tabular}

Pada Tabel 5, hasil pengujian variabel volume perdagangan saham menunjukan nilai signifikasi $>0.05$ yaitu sebesar 0.732 . Oleh sebab itu maka $\mathrm{H}_{0}$ diterima dan dapat disimpulkan bahwa tidak terdapat perbedaan yang signifikan pada abnormal return saham sebelum dan sesudah stock split.

Tabel 5. Hasil Uji untuk variabel Volume Perdagangan Saham

\begin{tabular}{|l|r|}
\hline & $\begin{array}{c}\text { Return Sesudah }- \\
\text { Return Sebelum }\end{array}$ \\
\hline $\mathrm{Z}$ & $-.343^{\mathrm{b}}$ \\
$\begin{array}{l}\text { Asymp. Sig. (2- } \\
\text { tailed) }\end{array}$ & .732 \\
\hline
\end{tabular}

Stock split memiliki pengaruh terhadap volume perdagangan saham dan harga saham $\left(\mathrm{H}_{1}\right.$ dan $\mathrm{H}_{2}$ diterima). Hasil penelitian ini sesuai dengan penelitian sebelumnya yang dilakukan oleh Mulyanto (2006), Hasna (2013), Rusliati dan Farida (2015). Namun hasil penelitian ini tidak sesuai dengan penelitian sebelumnya yang dilakukan oleh Farinha dan Basilio (2006). 
Hasil pengujian ini mendukung Trading Range Theory yang menyatakan bahwa stock split digunakan sebagai alat untuk mengatur kembali harga saham pada kisaran yang diinginkan oleh perusahaan sehingga dapat meningkatkan likuiditas perdagangan saham. Sedangkan stock split tidak berpengaruh terhadap abnormal return saham $\left(\mathrm{H}_{3}\right.$ ditolak).

Hasil penelitian ini sesuai dengan penelitian sebelumnya yang dilakukan oleh Fatimah (2010) dan Sadikin (2011). Namun hasil penelitian ini tidak sesuai dengan penelitian sebelumnya yang dilakukan oleh Leung (2005), Mulyanto (2006).

Hasil pengujian ini tidak sesuai dengan Signalling Theory yang menyatakan bahwa corporate action merupakan pemberian sinyal yang positif kepada investor bahwa kinerja perusahaan kedepannya diyakini akan terus meningkat dan memberikan return yang menguntungkan, stock split yang dilakukan oleh perusahaan diinterpretasikan oleh investor sebagai sinyal positif yang ditandai dengan munculnya abnormal return di sekitar tanggal pengumuman stock split.

Adapun penyebab dari ketidaksesuaian antara teori dengan hasil penelitian ini dapat disebabkan oleh beberapa hal sebagai berikut: Terdapat berbagai faktor lain yang dapat mempengaruhi abnormal return saham suatu perusahaan, misalkan faktor ekonomi makro seperti adanya kenaikan tingkat suku bunga dan faktor internal berupa kinerja perusahaan itu sendiri. Periode pengamatan (event period) yang digunakan dalam penelitian ini tergolong cukup singkat yaitu hanya selama 14 hari. Tidak menutup kemungkinan bahwa singkatnya periode pengamatan tersebut belum sepenuhnya dapat mengakomodir efek dari stock split terhadap abnormal return saham.

\section{KESIMPULAN DAN SARAN}

Hasil penelitian menunjukkan terdapat perbedaan volume perdagangan saham dan harga saham sebelum dan setelah perusahaan melakukan pemecahan saham (stock split).

Tidak terdapat perbedaan abnormal return saham sebelum dan setelah perusahaan melakukan pemecahan saham (stock split).

Dengan demikian, hasil penelitian juga memberikan saran terhadap investor bahwa informasi yang terjadi di pasar modal tidak semua merupakan informasi yang benar, karena itu pelaku pasar modal harus secara tepat memilah dan menganalisis informasiinformasi yang relevan untuk dijadikan pertimbangan dalam pengambilan keputusan.

Bagi penelitian selanjutnya, penelitian ini diharapkan dapat digunakan sebagai tambahan referensi di masa yang akan datang untuk dikembangkan dan diperbaiki. Misalnya dengan memperbanyak sampel penelitian dan memperpanjang periode pengamatan karena akan memperjelas perbedaan masing-masing variabel dengan adanya aktivitas split yang berkaitan dengan volume perdagangan saham, harga saham, dan abnormal return saham.

\section{DAFTAR PUSTAKA}

Alteza, Muniya. 2008. Kinerja Keuangan dan Harga Saham sebagai Determinan Keputusan Stock Split : Studi Empiris terhadap Perusahaan Terdaftar di BEJ. Jurnal Usahawan

Ang, Robert. 2012. Buku Pintar Pasar Modal Indonesia. Jakarta : Mediasoft Indonesia.

Brigham and Houston. 2006. Dasar-Dasar Manajemen Keuangan. Buku Dua, Edisi Kesepuluh. Jakarta : Salemba Empat.

Damayanti, Ni Luh. Anantawikrama, dan Nyoman. 2014. Analisis Pengaruh Pemecahan Saham (Stock Split) Terhadap Tingkat Keuntungan (Return) Saham dan Likuiditas Saham. e-Journal S1 Akuntansi Universitas Pendidikan Ganesha.

Fatmawati, Sri. dan Marwan, Asri. 2008. Pengaruh Stock Split Terhadap Likuiditas Saham yang Diukur dengan Besarnya Bid-Ask Spread di Bursa Efek Jakarta. Jurnal Riset Akuntansi. 
Fortuna, Chotyahani Hasna Rizka. 2010. Analisis Pengaruh Stock Split Terhadap Harga Saham pada Perusahaan Go Public di Bursa Efek Indonesia. Skripsi. Program Sarjana Universitas Diponegoro

Jogiyanto, Hartono. 2008. Teori Portofolio dan Analisis Investasi. Edisi Kelima.

Hasna, Chotyahani Rizka Fortuna. 2013. Analisis Pengaruh Stock Split terhadap Harga Saham Pada Perusahaan Go Public Di Bursa Efek Indonesia. Skripsi Ekonomi, Program Sarjana Petra. Surabaya.

Husnan, Suad. 2005. Dasar - dasar Teori Portofolio dan Analisis Sekuritas, Edisi Keempat. Yogyakarta: BPFE.

Ika, A dan Anna Purwaningsih. 2008. Reaksi Pasar Terhadap Pengumuman Stock Split : Studi Empiris Pada Perusahaan Manufaktur yang Terdaftar di Bursa Efek Jakarta. Jurnal Manajemen. Vol. 3 No. 1, hal 55-62

Koetin, E.A. (2000). Suatu Pedoman Invetasi Indonesia. Jakarta: Sinar Harapan.

Martono, SU. dan Harjito, Agus. 2002. Manajemen Keuangan, Edisi Pertama.

Marwata. (2011). Kinerja Keuangan, Harga Saham, dan Pemecahan Saham. Jurnal Riset Akuntansi Indonesia, Vol.4, no.2.

Mulyanto, Widodo Hari. 2006. Analisis Kinerja Saham Di Seputar Pengumuman Pemecahan Saham. Tesis diterbitkan. Semarang: Program Pasca Sarjana Universitas Diponegoro.

Permata, Nurlaela. 2009. Analisis Pengaruh Stock Split pada Harga Saham terhadap Volume Perdagangan di Bursa Efek Indonesia. Jurnal Ekonomi. Universitas Gunadarma.

Prasetyo, Hendrik. 2016. Stock Split terhadap Harga Saham pada Perusahaan Go Public di Bursa Efek Indonesia. Jurnal Riset Mahasiswa Vol 4 No. 1. Universitas Kanjuruhan Malang

Rusdin. 2008. Pasar Modal: Teori, Masalah, dan Kebijakan dalam Praktik.

Rusliati, Ellen dan Farida, Esti Nur. 2010. "Pemecahan Saham Terhadap Likuiditas dan Return Saham”. Jurnal Bisnis dan Akuntansi. Vol 12, No 3, Desember 2015

Samsul, Mohammad. (2006). Pasar Modal dan Manajemen Portofolio. Jakarta: Erlangga.

Sugiono, Arif dan Untung, Edy. 2008. Panduan Praktis dan Dasar Analisis Laporan Keuangan. Jakarta : Grasindo.

Widiastuti, H., dan Usmara. 2005. Analisis Faktor-Faktor yang Mempengaruhi Stock Split dan Pengaruhya Terhadap Nilai Perusahaan. Jurnal Akuntansi dan Investasi, 6, 225-241. 